\title{
KEBIASAAN BELAJAR BAHASA ARAB SISWA KELAS \\ UNGGULAN (Penelitian Etnografi di MTsN \\ Batusangkar TP. 2011/2012)
}

\author{
Nurlaila \\ Program Studi Pendidikan Bahasa Arab Sekolah Tinggi Agama Islam Negeri Batusangkar \\ Korespondensi: Jl. Sawah Tabing No. 10 Rambatan Batusangkar, Sumatera Barat \\ e-mail: nur.laila304@gmail.com
}

\begin{abstract}
This study aimed at identifying, describing and understanding students' learning habit at school and at home as well, and figuring out contributing factors in establishing and developing their habits. This study employed ethnography method and such techniques as observation, interview, documentary studies and questionnaire. The obtained data were analyzed by means of domain, taxonomy and componential analyses. Findings showed that the learning habits of the majority students of outstanding achievement class (kelas unggulan) of MTsN Batusangkar both at school and at home were good. Those habits were in line with achievement which they took is a reward. Satisfaction toward the reward encouraged them to be more motivated in learning which in turn developed better learning habit. These had formed a good chain in learning process. Factors that contributed to the establishment and development of learning habit were internal (self motivation, management, direction and development) and external factors (social and instrumental environments).
\end{abstract}

Kata kunci: siswa, kebiasaan belajar, bahasa Arab, kelas unggulan

\section{PENDAHULUAN}

$O$ ecara garis besar, proses dan hasil belajar siswa dipengaruhi oleh beberapa faktor, baik yang berasal dari luar diri siswa (faktor eksternal) maupun faktor yang berasal dari dalam diri siswa (faktor internal) (Purwanto, 2007: 107). Adapun yang termasuk faktor luar antara lain faktor lingkungan, baik lingkungan alam maupun lingkungan sosial, dan faktor instrumental seperti kurikulum, guru, sarana dan prasarana. Sedangkan yang termasuk faktor dalam antara lain faktor fisiologis dan psikologis, dan kebiasaan belajar merupakan salah satu faktor psikologis yang mempengaruhi hasil belajar.

Di sekolah sering ditemui siswa yang memiliki tingkat kecerdasan yang tinggi namun prestasi belajarnya masih rata-rata atau di bawah potensinya. Sebaliknya juga ditemui siswa yang memiliki tingkat kecerdasan cukup namun prestasi belajarnya di atas rata-rata atau melebihi potensinya. Hal ini bisa di pengaruhi oleh faktor kebiasaan belajar siswa, karena dua orang yang melakukan pekerjaan yang sama dimungkinkan tidak akan mencapai hasil yang sama jika keduanya memiliki kebiasaan yang berbeda.

Dalam upaya memberikan pelayanan pendidikan yang maksimal bagi peserta didik, beberapa sekolah reguler melakukan program kelas unggulan yaitu menempatkan siswa-siswa yang memiliki kemampuan lebih dibanding siswa pada umumnya dalam satu kelas, hal ini dilakukan agar siswa tersebut mendapat 
perlakuan yang sesuai dengan kemampuan mereka dalam pembelajaran.

MTsN Batusangkar merupakan madrasah yang berlokasi di pusat kota Batusangkar dan menjadi madrasah inti di Kabupaten Tanah Datar. Karena lokasinya yang strategis, MTsN Batusangkar termasuk madrasah dengan peminat yang cukup tinggi. Rata-rata per tahunnya, pendaftar berjumlah 200$300 \%$ dari daya tampung madrasah. Karena peminat yang cukup tinggi tersebut, MTsN Batusangkar cukup selektif dalam menentukan input yang akan diterima sebagai calon siswa.

Dengan input yang cukup berkualitas, MTsN Batusangkar memiliki peluang besar untuk melaksanakan program kelas unggulan dan MTsN Batusangkar telah menerapkan program tersebut sejak Tahun Pelajaran 1993/1994 untuk kelas II dan kelas III (sekarang kelas VIII dan kelas IX).

Prestasi siswa kelas unggulan MTsN Batusangkar sangat memuaskan. Secara umum, dapat dilihat dari berbagai prestasi yang diperoleh di dalam dan di luar madrasah. Secara khusus, dalam pelajaran Bahasa Arab siswa kelas unggulan memiliki tingkat prestasi yang lebih dibanding siswa kelas lainnya. Menurut Djaali (2008: 101), banyak faktor yang mempengaruhi dalam proses belajar untuk mencapai prestasi tersebut, antara lain motivasi, sikap, minat, kebiasaan belajar dan konsep diri.

Kebiasaan merupakan satu diantara faktor intern yang dialami dan dihayati oleh siswa yang berpengaruh pada proses belajar (Dimyati, 2006: 246). Menurut Syah (2004: 118) bahwa setiap siswa yang telah mengalami proses belajar maka kebiasaan-kebiasannya akan berubah. Burghardt (dalam Syah) mengemukakan bahwa kebiasaan itu timbul karena proses penyusutan kecenderungan respons dengan menggunakan stimulasi yang berulang-ulang. Dalam proses belajar, pembiasaan juga meliputi pengurangan perilaku yang tidak diperlukan. Karena proses penyusutan atau pengurangan inilah muncul suatu pola bertingkah laku baru yang relatif menetap dan otomatis.

Penelitian ini difokuskan pada masalah kebiasaan belajar Bahasa Arab siswa kelas unggulan MTsN Batusangkar. Fokus masalah diuraikan menjadi sub fokus kebiasaan belajar Bahasa Arab dan proses pengembangan kebiasaan belajar tersebut. Berdasarkan fokus dan sub fokus tersebut, maka masalah penelitian dirumuskan sebagai berikut: Bagaimana kebiasaan belajar Bahasa Arab siswa kelas unggulan MTsN Batusangkar dan proses pengembangannya?

\section{KAJIAN TEORI}

Belajar merupakan suatu proses, sutu kegiatan dan bukan suatu hasil atau tujuan. Belajar bukan hanya mengingat, akan tetapi lebih luas daripada itu, yakni mengalami. Hasil belajar bukan suatu penguasaan hasil latihan, melainkan perubahan tingkah kelakuan (Hamalik, 2003: 36).

Proses belajar sebagai sebuah proses perubahan tingkah laku dimana seseorang yang awalnya tidak mengetahui menjadi mengetahui, tidak mengerti menjadi mengerti, akan menghasilkan sesuatu. Dalam dunia pendidikan hasil dari suatu proses belajar adalah prestasi belajar. Prestasi belajar sendiri merupakan hasil penilaian pendidik terhadap proses belajar dan hasil belajar siswa.

Dalam proses belajar untuk mencapai prestasi tersebut, banyak faktor yang mempengaruhinya, antara lain motivasi, sikap, minat, kebiasaan belajar dan konsep diri (Djaali, 2008: 101). Kebiasaan Belajar adalah sesuatu yang biasa dikerjakan pada saat belajar secara teratur dan terarah, keteraturan di dalam belajar untuk mencapai keberhasilan (Martensi, 1980: 146). Menurut Djaali kebiasaan belajar adalah cara-cara atau teknik-teknik yang dilakukan siswa pada 
waktu ia menerima pelajaran dari guru, membaca buku dan mengerjakan tugastugas sekolah, serta pengaturan waktu untuk menyelesaikan kegiatan-kegiatan tersebut (Djaali, 2008: 128).

Gilmer (dalam Djaali, 2008: 128) mengemukakan bahwa kebiasaan belajar cenderung menguasai perilaku siswa pada setiap kali mereka melakukan kegiatan belajar. Sebabnya ialah karena kebiasaan mengandung motivasi yang kuat. Selanjutnya Djaali menegaskan bahwa pada umumnya setiap orang bertindak berdasarkan force of habit sekalipun ia tahu, bahwa ada cara lain yang mungkin lebih menguntungkan. Hal ini disebabkan oleh kebiasaan sebagai cara yang mudah dan tidak memerlukan konsentrasi dan perhatian yang besar. Sesuai dengan law of effect dalam belajar, perbuatan yang menimbulkan kesenangan cenderung untuk diulang. Oleh karena itu tindakan berdasarkan kebiasaan bersifat mengukuhkan (reinforcing). Sehingga rumusan mengenai cara-cara belajar yang efisien pun belum menjamin keberhasilan dalam belajar, namun yang paling penting bisa mempraktikkannya dalam belajar seharihari.

Banyak orang yang belajar dengan susah payah, tetapi tidak mendapatkan hasil yang maksimal. Hal ini disebabkan karena belajar tidak teratur, tidak disiplin, kurang bersemangat, tidak tahu bagaimana cara berkonsentrasi dalam belajar, mengabaikan masalah pengaturan waktu dalam belajar, istirahat yang tidak cukup, atau kurang tidur. Slameto (2003: 73) berpendapat bahwa banyak siswa gagal belajar akibat karena mereka tidak mempunyai kebiasaan belajar yang baik.

Kebiasaan belajar siswa akan menjadi tradisi yang dianut oleh siswa yang akan selalu melekat di dalam setiap tindakan dan perilaku siswa sehari-hari baik di sekolah, di rumah maupun di lingkungan masyarakat. Misalnya tradisi dalam memanfaatkan waktu belajar, disiplin dalam belajar, kegigihan/ke- uletan dalam belajar, dan konsisten dalam menerapkan cara belajar efektif.

Kebiasaan belajar yang baik mengandung suatu ketetapan, keteraturan menyelesaikan tugas, dan menghilangkan rangsangan yang akan mengganggu konsentrasi belajar sehingga semua itu akan berpengaruh terhadap prestasi belajarnya. Kepribadian yang teratur sebagai salah satu barometer dari kejernihan berpikir. Kejernihan berpikir yang diperlukan selama menuntut ilmu harus dipertahankan. Demikian pula sebaliknya, kebiasaan yang kurang baik akan membentuk siswa menjadi pribadi yang malas, bertindak semaunya, dan ketidakteraturan. Kebiasaan belajar tidak dapat dibentuk dalam waktu satu hari atau satu malam. Kebiasaan belajar perlu dikembangkan sedikit demi sedikit.

Untuk membentuk kebiasaan dibutuhkan pembiasaan. Menurut Ngalim Purwanto (2009: 177) pembiasaan adalah salah satu alat pendidikan yang penting sekali, terutama bagi anak-anak yang masih kecil. Anak-anak kecil belum menginsafi apa yang dikatakan baik dan apa yang dikatakan buruk dalam arti susila. Juga anak kecil belum mempunyai kewajiban-kewajiban yang harus dikerjakan seperti orang dewasa, tetapi mereka sudah mempunyai hak seperti hak dipelihara, hak mendapat perlindungan, dan hak mendapat pendidikan. Anak kecil belum kuat ingatannya, ia cepat melupakan apa yag sudah dan baru terjadi. Perhatian mereka mudah beralih kepada hal-hal yang baru, yang lain, yang disukainya. Apalagi pada anakanak yang baru lahir, hal itu semua belum ada sama sekali atau setidaknya belum sempurna.

Anak-anak dapat menurut dan taat kepada peraturan-peraturan dengan jalan membiasakannya dengan perbuatanperbuatan yang baik, di dalam rumah tangga atau keluarga, di sekolah dan juga di tempat lain. Pembiasaan yang baik penting artinya bagi pembentukan watak anak-anak, dan juga aka teus berpengaruh kepada anak itu sampai hari tuanya. 
Menanamkan kebiasaan pada anak-anak adalah sukar dan kadang-kadang memakan waktu yang lama. Maka dari itu, lebih baik menjaga anak-anak supaya mempunyai kebiasaan-kebiasaan yang baik daripada terlanjur memiliki kebiasaan-kebiasaan yang tidak baik.

Syah (2004: 123-124) mengemukakan bahwa salah satu dari jenis-jenis belajar adalah belajar kebiasaan, yaitu proses pembentukan kebiasaan-kebiasaan baru atau perbaikan kebiasaan-kebiasaan yang telah ada. Belajar kebiasaan, selain menggunakan perintah, suri teladan dan pengalaman khusus, juga menggunakan hukuman dan ganjaran. Tujuannya agar siswa memperoleh sikap-sikap dan kebiasaan-kebiasaan perbuatan baru yang lebih tepat dan positif dalam arti selaras dengan kebutuhan ruang dan waktu (kontekstual).

Menurut Dimyati (2006: 246-247), dalam kegiatan sehari-hari ditemukan ada kebiasaan belajar yang kurang baik. Kebiasaan belajar yang kurang baik tersebut antara lain berupa (1) belajar pada akhir semester saja, (2) belajar tidak teratur, (3) menyia-nyiakan kesempatan belajar, (4) bersekolah hanya untuk bergengsi, (5) datang terlambat bergaya pemimpin, (6) bergaya jantan seperti merokok, sok menggurui teman lain, dan (7) bergaya minta belas kasihan tanpa belajar. Kebiasaan-kebiasaan buruk tersebut dapat ditemukan di sekolah yang ada di kota besar, kota kecil, dan dipelosok tanah air. Untuk sebagian, kebiasaan belajar tersebut disebabkan oleh ketidakmengetian siswa pada arti belajar bagi diri sendiri yang dapat diperbaiki dengan pembinaan disiplin membelajarkan diri.

\section{METODE PENELITIAN}

Pertanyaan penelitian yang akan dijawab melalui penelitian ini sebagai berikut:
1. Bagaimana kebiasaan belajar Bahasa Arab siswa kelas unggulan di sekolah?

2. Bagaimana kebiasaan belajar Bahasa Arab siswa kelas unggulan di rumah?

3. Bagaimana proses pengembangan kebiasaan belajar Bahasa Arab siswa kelas unggulan?

Penelitian ini bertujuan untuk mengidentifikasi, mendeskripsikan dan mendapatkan makna dari kebiasaan belajar Bahasa Arab siswa kelas unggulan MTsN Batusangkar yang mencakup aspek (1) kebiasaan belajar Bahasa Arab siswa kelas unggulan di sekolah, (2) kebiasaan belajar Bahasa Arab siswa kelas unggulan di rumah, dan (3) faktor internal dan eksternal dalam proses pengembangan kebiasaan belajar Bahasa Arab siswa kelas unggulan.

Penelitian ini dilakukan di MTsN Batusangkar TP. 2011/2012. Penelitian ini menggunakan metode etnografi yaitu uraian dan penafsiran suatu budaya atau sistem kelompok sosial. Peneliti mempelajari pola perilaku, kegiatan, kebiasaan, kepercayaan dan cara hidup suatu kelompok. Inti etnografi adalah upaya untuk memperlihatkan makna-makna tindakan dari kejadian pada orang yang ingin kita pahami. Beberapa makna tersebut terekspresikan secara langsung dalam bahasa, dan di antara makna yang diterima, banyak yang disampaikan hanya secara tidak langsung melalui kata-kata dan perbuatan. Hasil akhir penelitian komprehensif etnografi adalah suatu naratif deskriptif yang bersifat menyeluruh disertai interpretasi yang menginterpretasikan seluruh aspek-aspek kehidupan dan mendeskripsikan kompleksitas kehidupan tersebut

Sumber data penelitian ini terdiri dari siswa kelas VIII 1, siswa kelas IX 1, guru Bahasa Arab, wakil kepala madrasah bidang kurikulum dan dokumendokumen yang dibutuhkan. Teknik pe- 
ngumpulan data berupa observasi, wawancara, dokumentasi dan kuesioner. Data yang diperoleh dianalisis melalui analisis domain, analisis taksonomi dan analisis kompenisial.

\section{HASIL PENELITIAN DAN PEM- BAHASAN}

Keberadaan kelas unggulan di MTsN Batusangakar bukan semata-mata ambisi kelembagaan, lebih dari itu untuk menjawab tantangan global dan harapan semua pihak. Menurut wakil kepala madrasah bidang kurikulum, pelaksanaan program kelas unggulan di MTsN Batusangkar memiliki tujuan untuk (1) memberikan kesempatan bagi siswasiswa yang berpotensi untuk bisa mengembangkan potensinya, (2) memberikan kemudahan bagi madrasah untuk lebih fokus melakukan pembinaan, menyeleksi dan memilih siswa-siswa yang akan diutus untuk mengikuti berbagai ajang perlombaan, dan (3) memudahkan guru dalam proses pembelajaran.

Kurikulum yang digunakan tetap mengacu pada KTSP, dan dalam pelaksanaan pembelajaran tidak terdapat perbedaan dengan kelas reguler lainnya. Kelas unggulan diisi oleh siswa yang diseleksi berdasarkan nilai rapor pada semester sebelumnya. Pada tahun pelajaran 2011/2012 kelas ungulan di MTsN Batusangkar terdiri dari dua kelas yaitu kelas VIII-1 dan kelas IX-1.

\section{Analisis Domain}

Kebiasaan belajar Bahasa Arab siswa kelas unggulan MTsN Batusangkar untuk setiap aspek kebiasaan yang diteliti yaitu (1) kebiasaan belajar Bahasa Arab di sekolah; kebiasaan sebelum belajar, sewaktu mengikuti pembelajaran di kelas dan kebiasaan belajar di luar kelas, dan (2) kebiasaan belajar Bahasa Arab di rumah; kebiasaan menyusun rencana dan jadwal belajar, menyiapkan perlengkapan belajar, menyelesaikan tugas dan cara belajar.

Kebiasaan belajar Bahasa Arab siswa kelas unggulan MTsN Batusangkar diketahui melalui pengisian angket oleh siswa sebanyak 37 item dengan skor tertinggi 5 dan skor terendah 1. Berdasarkan hasil pengisian angket tersebut diperoleh data bahwa tidak ada siswa yang memiliki kebiasaan belajar Bahasa Arab yang tidak baik maupun kurang baik. Siswa kelas unggulan yang memiliki kebiasaan belajar Bahasa Arab yang tergolong sangat baik sebanyak 6,8\%,. Sedangkan mayoritas siswa kelas unggulan memiliki kebiasaan belajar Bahasa Arab yang baik yaitu 76,3\%. Dan sisanya $16,9 \%$ memiliki kebiasaan belajar Bahasa Arab yang cukup baik.

\section{Analisis Taksonomi}

Kebiasaan belajar tersebut tidak terbentuk dalam waktu satu atau dua hari, melainkan membutuhkan proses sampai perilaku belajar tersebut menetap pada diri siswa dan menguasai perilaku siswa pada setiap kali mereka melakukan kegiatan belajar, sehingga dapat disebut sebagai kebiasaan.

Berdasarkan wawancara dengan siswa kelas unggulan, diketahui bahwa kebiasaan belajar mereka terbentuk dan berkembang karena beberapa faktor, diantaranya faktor motivasi dari dalam diri mereka sendiri. Siswa-siswa kelas unggulan menyadari betapa pentingnya ilmu pengetahuan dan mereka merasa senang ketika mengetahui sesuatu yang baru dan menyadari bahwa pengetahuannya bertambah. Motivasi yang tinggi tersebut akan menuntun mereka untuk selalu belajar dan belajar. Disamping itu mereka juga memiliki motivasi berprestasi yang tinggi, yaitu dorongan pada diri siswa untuk meningkatkan atau mempertahankan prestasi, baik dalam pencapaian prestasi yang lebih tinggi dibandingkan dengan prestasi yang 
pernah diraih sebelumnya maupun dibandingkan dengan prestasi orang lain.

Berdasarkan hasil wawancara tersebut tergambar bahwa motivasi diri siswa merupakan modal utama dalam mengembangkan kebiasaan belajar Bahasa Arab siswa. Siswa-siswa kelas unggulan memiliki motivasi yang tinggi untuk belajar dan berprestasi. Menurut Gilmer (dalam Djaali, 2008: 128) bahwa kebiasaan belajar cenderung menguasai perilaku siswa pada setiap kali mereka melakukan kegiatan belajar. Sebabnya ialah karena kebiasaan mengandung motivasi yang kuat.

Di samping motivasi, siswa kelas unggulan juga memiliki manajemen diri yang baik. Berdasarkan hasil wawancara, diperoleh informasi bahwa siswa kelas unggulan sangat teliti dalam mengatur waktu, benda, dokumen, tenaga, pikiran dan semua sumber daya dalam kehidupannya. Siswa kelas unggulan juga teliti dalam mengatur benda, dokumen dan berkas-berkas tertentu.

Manajemen diri ini dibarengi dengan pengendalian atau kontrol terhadap diri sendiri. Berdasarkan wawancara dengan siswa kelas unggulan, maka diperoleh data bahwa menurut mereka, untuk dapat melaksanakan jadwal kegiatan belajar harian memerlukan pengendalian diri yang tinggi dan tekad yang kuat. Mereka menyadari bahwa banyak gangguan dalam belajar, sehingga untuk tetap konsisten maka dibutuhkan pengendalian diri guna melawan semua ganggguan tersebut.

Siswa kelas unggulan juga aktif dalam berbagai kegiatan ekstrakurikuler yang dilaksanakan oleh sekolah. Menurut mereka hal ini sangat berguna untuk pengembangan diri, baik yang bersifat spritual, emosional maupun keterampilan. Pengembangan diri siswa juga memberikan kontribusi terhadap pengembangan kebiasaan belajar yang baik.
Di samping karena faktor internal dari diri siswa, kebiasaan belajar siswa kelas unggulan juga dipengaruhi oleh faktor eksternal. Orang tua adalah salah satu faktor luar yang sangat berperan dalam membentuk dan mengembangkan kebiasaan belajar siswa kelas unggulan. Berdasarkan wawancara dengan salah satu siswa, diperoleh informasi bahwa orang tuanya selalu mengontrol kegiatan belajarnya baik kegiatan belajar di rumah ataupun di sekolah. Orang tua yang selalu mengawasi sang anak dan menekan seminimal mungkin hal-hal negatif mempengaruhi konsentrasi belajar anak tentu akan membuat anak merasa sangat nyaman dalam belajar sehingga mereka akan belajar dengan baik dan memanfaatkan waktu dengan efektif. Kontrol penuh dari orang tua membuat siswa-siswa tersebut selalu belajar dengan baik di rumah dan di sekolah.

Iklim sekolah yang diciptakan oleh semua unsur di sekolah tersebut juga menjadi faktor penting dalam terbentuknya kebiasaan belajar siswa. Berdasarkan observasi peneliti dan wawancara dengan guru Bahasa Arab maka diperoleh data bahwa guru selalu berupaya menumbuhkan kebiasaan berkonsentrasi dalam belajar pada diri siswa. Artinya, sikap (attitude) guru Bahasa Arab yang memperhatikan setiap siswa saat proses pembelajaran berperan penting dalam membentuk kebiasaan belajar siswa, seperti kebiasaan berkonsentrasi ketika belajar di kelas, kebiasaan mengerjakan tugas, kebiasaan disiplin dalam waktu baik berupa kehadiran di kelas maupun waktu untuk izin selama pelajaran berlangsung, dan lain-lain. Guru sebagai faktor eksternal menjadi faktor penting dalam terbentuknya kebiasaan belajar siswa.

Menurut Burghardt (dalam Syah, 2004: 118) bahwa kebiasaan itu timbul karena proses penyusutan kecenderung- 
an respons dengan menggunakan stimulasi yang berulang-ulang. Dalam proses belajar, pembiasaan juga meliputi pengurangan perilaku yang tidak diperlukan. Karena proses penyusutan atau pengurangan inilah muncul suatu pola bertingkah laku baru yang relatif menetap dan otomatis.

Menguatkan pendapat ini, The Liang Gie (1980: 15) menegaskan bahwa disiplin belajar akan membuat siswa memiliki kecakapan mengenai cara belajar dan juga merupakan proses ke arah pembentukan watak yang baik. Cara belajar dapat dimiliki oleh siswa dengan latihan yang teratur dan sungguh-sungguh. Kalau cara belajar yang baik telah menjadi kebiasaan maka tidak ada lagi anjuran-anjuran dari guru yang harus selalu diperhatikan sewaktu belajar
Dengan demikian, upaya-upaya yang dilakukan orang tua dan guru dalam mengembangkan kebiasaan belajar pada siswa merupakan upaya dalam menekan kecenderungan yang negatif dan mengembangkan kebiasaan yang positif dengan menggunakan stimulasi yang berulang-ulang. Karena proses penyusutan atau pengurangan perilaku negatif dan perilaku yang tidak diperlukan, maka muncul suatu pola bertingkah laku baru yang relatif menetap dan otomatis yang disebut kebiasaan.

Berdasarkan penjelasan di atas, maka dapat diklasifikasikan faktor-faktor yang berperan dalam membentuk dan mengembangkan kebiasaan belajar siswa kelas unggulan MTsN Batusangkar sebagaimana tergambar pada bagan berikut:

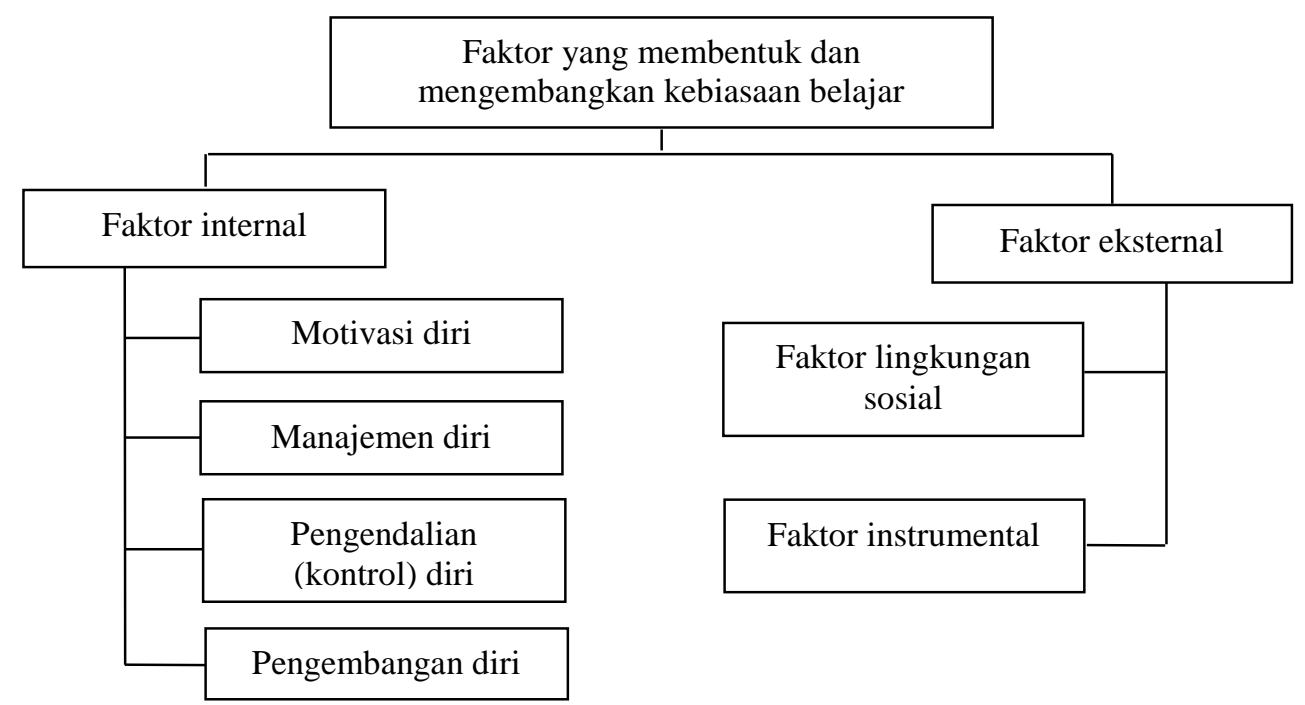

Kebiasaan belajar yang tinggi ini berbanding lurus dengan hasil belajar bahasa

Arab siswa kelas unggulan. Inteligensi tinggi dari siswa kelas unggulan yang diiringi dengan kebiasaan belajar yang baik tentu akan membuahkan prestasi yang tinggi. Menurut Djaali (2008: 128), rumusan mengenai cara-cara belajar yang efisien belum menjamin keberhasilan dalam belajar, yang paling penting bisa mempraktikkannya dalam belajar sehari-hari sehingga lama-kelamaan menjadi kebiasaan, baik di dalam maupun di luar kelas. Slameto (2003: 73) berpendapat bahwa banyak siswa gagal belajar akibat karena mereka tidak mempunyai kebiasaan belajar yang baik. Bahkan hasil penelitian Henry Clay Lindgren (Gie, 1995: 194) terhadap sejumlah mahasiswa di San Fransisco State College menunjukkan bahwa kebiasaan yang baik menyumbang 33\% terhadap keberhasilan mereka. Dari hasil penyelidikan itu ternyata kebiasaan berperan penting bagi kesuksesan mereka. Kecerdasan tidak dianggap sebagai faktor utama dalam mencapai sukses.

Dengan demikian kebiasaan belajar sangat penting untuk mencapai 
hasil belajar yang baik, siswa yang memiliki kebiasaan belajar yang baik akan dapat meningkatkan pencapaian prestasi belajar yang baik pula dan sebaliknya. Dengan hasil belajar yang baik maka seseorang akan mendapatkan penghargaan yang tinggi dari orang lain. Kepuasan terhadap penghargaan tersebut akan mengobarkan motivasi belajar, dan motivasi akan mendorong berkembangnya kebiasaan belajar yang lebih baik lagi. Dengan demikian, terjadilah suatu mata rantai yang saling memacu dan menguntungkan dalam proses belajar yang dapat digambarkan sebagai berikut:

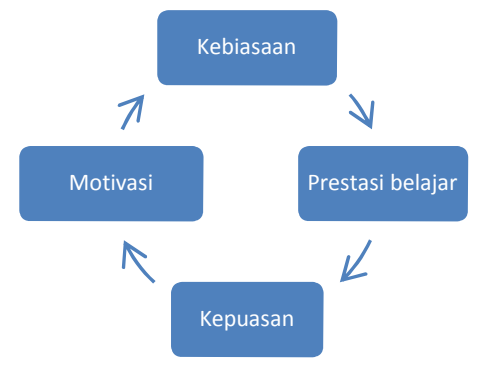

\section{Analisis Kompenisial}

Walaupun secara umum siswa kelas unggulan memiliki kebiasaan belajar Bahasa Arab yang baik, namun perilaku itu tidak ditampilkan oleh siswa dalam seluruh aspek kebiasaan belajar. Kebiasaan baik jarang ditampilkan oleh siswa dalam hal kebiasaan belajar di luar kelas.

Berdasarkan hasil observasi, MTsN Batusangkar sebagai madrasah terkemuka di Kabupaten Tanah Datar memiliki tenaga pengajar Bahasa Arab yang memadai. Sikap guru dalam mengajar tergolong baik dan dalam menyampaikan materi pelajaran guru tidak hanya menggunakan satu metode melainkan sudah bervariasi. Namun dalam pengembangan kebiasaan belajar tidak cukup hanya dengan beberapa faktor di atas. Masih ada faktor lain yang ikut berperan dalam pengembangan kebiasaan belajar Bahasa Arab siswa kelas unggulan. Berdasarkan hasl penelitian, ke- biasaan belajar Bahasa Arab siswa kelas unggulan di luar kelas tergolong rendah, hal ini bisa disebabkan oleh beberapa faktor, diantaranya tidak tersedianya referensi yang memadai terkait dengan mata pelajaran Bahasa Arab di perpustakaan, kurangnya kegiatan atau program (al-manasyith al-lughawiyyah) untuk berlatih kemahiran ber-Bahasa Arab dan tidak diciptakannya biah Bahasa Arab di sekolah ini.

Berdasarkan observasi, referensi Bahasa Arab yang terdapat di perpustakaan MTsN Batusangkar hanya kamus Bahasa Arab. Di perpustakaan ini tidak terdapat buku-buku penunjang mata pelajaran Bahasa Arab bagi siswa, seperti buku percakapan Bahasa Arab sehari-hari, komik atau majalah berbahasa Arab, kamus tematik dan lain-lain. Berdasarkan hasil wawancara, guru Bahasa Arab pernah mengajukan bukubuku tersebut dalam pengadaan buku di perpustakaan, namun karena alasan yang kurang jelas sampai sekarang keinginan tersebut belum terwujud.

Sedangkan media yang tersedia untuk berlatih kemahiran berbahasa Arab hanya pidato yang ditampilkan dalam acara muhadharah yang digelar sekali dalam seminggu (satu orang). Menurut informasi dari guru Bahasa Arab, tahun 2009 sekolah ini pernah memiliki sejenis klub bahasa yang menjadi media bagi siswa untuk berlatih pidato, puisi, lagu atau drama berbahasa Arab. Tapi karena satu alasan yang kurang jelas akhirnya kegiatan ini dihentikan. Namun menurut analisa guru Bahasa Arab tersebut, kegiatan ini dihentikan karena terkendala dana.

Mengenai aplikasi maharah kalam yang telah dipelajari di luar kelas sama sekali tidak ada, hal ini lebih disebabkan oleh tidak adanya tuntutan, baik dari guru ataupun sekolah, untuk menggunakan Bahasa Arab dalam komunikasi sehari-hari antar siswa ataupun dengan guru Bahasa Arab. Padahal untuk komu- 
nikasi yang sifatnya ringan, terutama antara siswa dengan guru, sebaiknya disarankan atau bahkan diwajibkan menggunakan Bahasa Arab sebagai sarana melatih maharah kalam dan melatih merangkai kosa kata yang telah dipelajari.

Djaali menegaskan bahwa pada umumnya setiap orang bertindak berdasarkan force of habit sekalipun ia tahu, bahwa ada cara lain yang mungkin lebih menguntungkan (Djaali, 2008: 128). Oleh karena itu kebiasaan belajar yang baik tetap harus dikembangkan karena kebiasaan belajar bukan faktor bawaan melainkan perilaku yang dipelajari dan dilakukan dengan cara sengaja dan sadar dalam beberapa waktu.

\section{PENUTUP}

Hasil penelitian menunjukkan bahwa kebiasaan belajar Bahasa Arab siswa kelas unggulan MTsN Batusangkar dalam hal kebiasaan belajar di rumah dan di sekolah- mayoritas tergolong baik dan tidak ada yang memiliki kebiasaan belajar Bahasa Arab kurang baik maupun tidak baik. Kebiasaan belajar tersebut berbanding lurus dengan hasil belajar. Dengan hasil belajar yang baik maka seseorang akan mendapatkan

\section{DAFTAR RUJUKAN}

Dimyati dkk, 2006. Belajar dan Pembelajaran, Jakarta: PT Rineka Cipta, Cet. ke-3

Djaali, 2008. Psikologi Pendidikan, Jakarta: Bumi Aksara, Cet, ke-3

Martensi, Mungin Edi Wibowo, 1980. Identifikasi Kesulitan Belajar, Semarang: FIP IKIP Semarang.

Muhibin Syah, 2004. Psikologi Pendidikan dengan Pendekatan Baru, Badung: PT Remaja Rosdakarya, Cet. ke- 10 penghargaan yang tinggi dari orang lain. Kepuasan terhadap penghargaan tersebut akan mengobarkan motivasi belajar, dan motivasi akan mendorong berkembangnya kebiasaan belajar yang lebih baik lagi, sehingga terjadilah suatu mata rantai yang saling memacu dan menguntungkan dalam proses belajar.

Faktor-faktor yang berperan dalam pembentukan dan pengembangan kebiasaan belajar Bahasa Arab siswa kelas unggulan terdiri dari faktor internal dan faktor eksternal. Faktor internal mencakup motivasi diri, manajemen diri, pengendalian diri dan pengembangan diri, sedangkan faktor eksternal mencakup faktor lingkungan sosial dan instrumental.

Berdasarkan kesimpulan diatas maka disampaikan beberapa saran:

1. Kebiasaan belajar Bahasa Arab di sekolah dan di rumah harus ditingkatkan sehingga dengan kebiasaan belajar yang baik diharapkan prestasi belajar akan meningkat.

2. Untuk meningkatkan kebiasaan belajar perlu adanya dukungan dari semua pihak, baik dari siswa sendiri, guru mata pelajaran, pihak sekolah, maupun orang tua.

Ngalim Purwanto, 2009. Ilmu Pendidikan Teoritis dan Praktis, Bandung: PT Remaja Rosdakarya, Cet. ke-19

Oemar Hamalik, 2003. Kurikulum dan Pembelajaran, Jakarta: Bumi Aksara, Cet. ke-4

Slameto, 2003. Belajar dan Faktorfaktor yang Mempengaruhinya. Cetakan ke-4, Jakarta: Rineka Cipta.

The Liang Gie, 1980. Cara Belajar yang Efisien, Jakarta: Gajah Mada University Press. 

belajar 1, 181, 182, 183, 184, 185, 186, 187, 188, 189

kebiasaan...1, 181, 182, 183, 184, 185, 186, $187,188,189$

madrasah

$181,184,188$

motivasi

$181,182,185,187,189$ prestasi...............1, 181, 182, 185, 187, 189 sekolah.......1, 181, 182, 183, 184, 185, 186, 188,189

siswa ..1, 181, 182, 183, 184, 185, 186, 187, 188,189 